\title{
Achieving Cooler Soil as an Effective Heat Sink for Earth-to-Air Heat Exchanger (EAHE) Cooling Technology in Malaysia Tropical Climate
}

\author{
Aliyah Nur Zafirah Sanusi, Aidil Azlan Ahmad Zamri \\ Kulliyyah of Architecture and Environmental Design, Intenational Islamic University Malaysia, \\ Kuala Lumpur, Malaysia \\ Email: aliyahsanusi@gmail.com, aliyah@iium.edu.my
}

Received 10 July 2014; revised 18 August 2014; accepted 30 August 2014

Copyright (C) 2014 by authors and Scientific Research Publishing Inc.

This work is licensed under the Creative Commons Attribution International License (CC BY).

http://creativecommons.org/licenses/by/4.0/

c) (i) Open Access

\section{Abstract}

This research is intended to explore the capacity of Malaysia soil in becoming a more effective heat sink for the application of Earth-to-Air Heat Exchanger (EAHE) Cooling Technology in Malaysia. EAHE Cooling Technology consists of buried pipes underground where the ambient air is channeled through from the pipe inlet and produces cooler air at its outlet. Within the buried pipes, heat exchange process occurs between the air and the soil that surrounding the pipe. This building cooling technology has been applied in many countries, mostly in temperate or hot and arid climate where the diurnal temperature is large. However, minimal resources were found on the study of EAHE application to buildings in Malaysia, hence there is room to develop. A parametric study on EAHE cooling application in Malaysia was done through field experiment and concluded that among many parameters affecting the technology performance, the soil temperature which surrounded the pipe was the most influential factor. The study recommended to further reduce the soil temperature to achieve a cooler outlet temperature. In response to that, this research conducted a parametric study of soil temperature under three different soil surface conditions: bare, shaded with timber pallettes and insulated with used tyres at $1.0 \mathrm{~m}$ and $1.5 \mathrm{~m}$ underground. The data was logged for a month and the result has shown significant reduction in the soil temperature underground below the shaded and insulated soil surface as compared to below bare soil surface condition. The insulated soil surface produced the best result where the soil temperature was reduced up to $26.9^{\circ} \mathrm{C}$. The main contribution of this paper is to highlight that the soil surface treatment can be used to reduce solar heat gain within the soil underground and thus improving the performance of EAHE Cooling Technology particularly for the application in Malaysia tropical climate. 


\section{Keywords}

\section{Ground Cooling, Green Technology, Earth-to-Air Heat Exchanger, Cooled Soil}

\section{Introduction}

Urban Heat Island (UHI) issue with maximum temperature rising up to $40^{\circ} \mathrm{C}$ that leads to human thermal comfort is affecting Malaysia energy consumption [1]. In Malaysia, building occupants often solve thermal discomfort with air-conditioning, which consumes more than $50 \%$ of the building total energy consumption [2]. This research is intended to find possible solutions in applying a better alternative building cooling system that would lead to mitigating the Urban Heat Island (UHI) issue and reduce energy consumptions in the future and Earth-to-Air Heat Exchanger (EAHE) cooling technology is further explored in becoming the better alternative building cooling in Malaysia.

EAHE Cooling Technology consists of buried pipes with two ends: pipe inlet and outlet, which act as a vehicle to channel ambient air into its inlet through to its outlet. When the soil temperature is cooler than the channelled ambient air, heat transfer process will occur within the buried pipe and a cooler ambient air is produced at the buried pipe outlet. This cooler air at the pipe outlet is utilized to cool the desired building space. The performance of EAHE Cooling Technology is affected by four main parameters: pipe diameter, pipe length, pipe burial depth and air flow rate within the pipe. In response to that, many researchers have agreed to similar conclusion that the EAHE pipe outlet temperature could be reduced for building cooling through the increasing pipe length, decreasing pipe diameter, decreasing air flow rate within the pipe and increasing pipe burial depths until the maximum of $4 \mathrm{~m}$ underground [3] and [4]. Krarti and Kreider concluded the heat transfer coefficient would increase when the buried structure was small. So, smaller pipes effectively transferred heat to the ground [5]. These researches and applications were carried out successfully in temperate and hot and arid countries. However, the EAHE Cooling Technology is rarely applied in Malaysia and yet to be explored further.

Reimann et al. reported the result of investigation on the performance of underground cooling in The CoolTek House in Melaka, Malaysia. The report stated that the air temperature delivered by the underground cooling system in the CoolTek was almost constant at $27.2^{\circ} \mathrm{C}$ throughout the day and night while the maximum air temperature was $32^{\circ} \mathrm{C}$ [6]. The CoolTek House achieved the maximum of $5^{\circ} \mathrm{C}$ reduction from the outside air temperature. A field investigation of EAHE cooling system was conducted in 2012 at a site in the Gombak Campus of International Islamic University Malaysia and a parametric study was carried out to evaluate the most effective design parameters in the EAHE cooling system in producing cooler air temperature at its pipe outlet [7]. The study concluded that $1 \mathrm{~m}$ depth was the most optimum depth because the soil temperature was stable and found to be the coolest in comparison to deeper soil. However, there was slight fluctuation in soil temperature at $1 \mathrm{~m}$ which was caused by heat gained from solar radiation onto the soil surface. Givoni (2007) [8] stated that shaded soil had lower average temperature. Therefore, enlightened by Givoni’s theory, this research responded to the findings by Sanusi (2012) [9] and developed methods of cooling the underground soil prior to further development of EAHE Cooling Technology that suits the local Malaysia climate.

The main aim is to evaluate the potential of cooling the soil underground prior to developing the low-energy EAHE Cooling Technology further for an efficient system for application in Malaysia hot and humid climate. The aim is supported by the following objectives:

- To obtain further temperature reductions of the soil underground for better heat transfer process of the EAHE Cooling buried pipes.

- To determine which soil surface condition provides the best cooled soil for EAHE Cooling Technology application.

- To simulate the EAHE cooling performance after the effect of cooled soil.

\section{Methodology}

Field investigation was the main part of this research and it was followed by simulation of EAHE Cooling Technology performance with effect of the field investigation data. The field investigation was carried out in the Gombak campus of International Islamic University Malaysia (IIUM) and the measurements were taken for one 
month in January. HOBO Pendant dataloggers were buried underground and measured the soil temperature at the interval of 15 minutes. The HOBO Pendant datalogger is a lightweight waterproof two-channel datalogger which measures temperature and relative light level. However, this experiment only concerns temperature data $\mathrm{f}$ the underground soil. It has dimension of $58 \times 33 \times 23 \mathrm{~mm}$ and weight $18 \mathrm{~g}$. It is able to measure temperature range from $-20^{\circ} \mathrm{C}$ to $70^{\circ} \mathrm{C}$ in air and from $0^{\circ} \mathrm{C}$ to $50^{\circ} \mathrm{C}$ in water. It is sealed with water-resistant housing for underwater use for depths up to 30 Meters (100 ft) [10].

The experiment site locates three separate spots where the data loggers were buried to measure the soil temperature at $1.0 \mathrm{~m}$ and $1.5 \mathrm{~m}$ depth. The three buried spots varies in soil surface condition: 1) Bare with short grass; 2) Sheltered by layers of recycled timber pallette and 3) Insulated by layers of used tyres (Figure 1). Table 1 listed the schedule of soil temperature measurements.

Parametric analysis was carried out for two purposes. The first was to ascertain that soil temperature at $1 \mathrm{~m}$ underground remain as the optimum EAHE system pipe depth. The second was to find the most effective soil surface condition. The parametric analysis was extended to the simulation of the EAHE performance in Energy Plus software, where field investigation data was inserted as part of the analysis input.

\section{Results and Discussion}

The investigation of soil temperature underground was conducted for one month in the month of January, hence the results presented for the month of January. Figure 2 shows the distribution of Dry Bulb Temperatures (DBT) for the month of January 2014. To summarise it, the DBT ranges from $21.5^{\circ} \mathrm{C}$ to $34.1^{\circ} \mathrm{C}$ in January. The average DBT came up to $26.6^{\circ} \mathrm{C}$.

In relation to Figure 2, Table 2 shows the summary of the soil temperature range at $1.0 \mathrm{~m}$ and $1.5 \mathrm{~m}$ depth underground under the three soil surface conditions.

Figure 3 shows the distribution of soil temperature at $1.0 \mathrm{~m}$ and $1.5 \mathrm{~m}$ depth underground under soil surface which are shaded with timber pallete and insulated with used tyres. Figure 3 shows that the soil temperature at $1.0 \mathrm{~m}$ depth buried under used tyres have the coolest temperature trend among the four sets of data. Figure 3 also shows the behaviour of the soil adapting to the new soil surface treatment. The soil was shaded and insulated at the beginning of the month; hence the soil temperature was slightly higher. The explanation for this is simply due to the time taken by the soil to release the heat gained from solar radiation before it being sheltered until the soil temperature settled 18 days after the soil surface treatment.

According to Banks (2008) [11], soil surface temperature could be reduced up to $10^{\circ} \mathrm{C}$ without any influence by highly intensed direct or diffused solar radiation (Figure 4).

Malaysia climate has solar radiation from 8:00 a.m. to 7:00 p.m. with high intensity particularly between

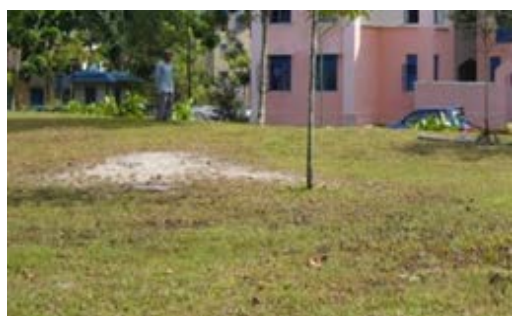

(a)

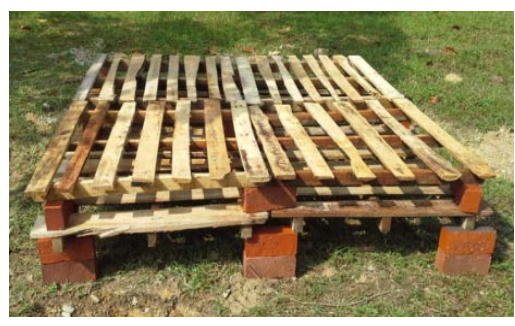

(b)

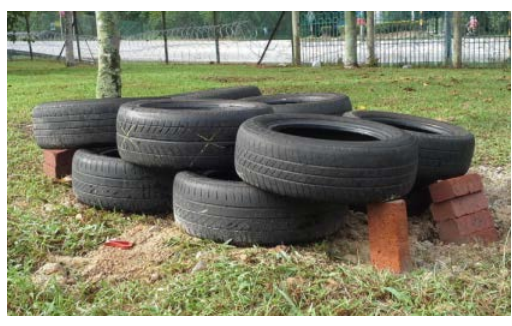

(c)

Figure 1. Three various condition of soil surface cover above the buried HOBO datalogger measuring soil temperature at $1.0 \mathrm{~m}$ and $1.5 \mathrm{~m}$ underground. (a) Bare soil surface with short grass; (b) Sheltered by layers of recycled timber palette; (c) Insulated by layers of used tyres.

Table 1. Schedule of soil temperature measurement.

\begin{tabular}{cccc}
\hline Soil surface condition & Bare soil surface with short grass & Sheltered by timber pallette & Insulated by used tyres \\
\hline Depth 1 & $1.0 \mathrm{~m}$ & $1.0 \mathrm{~m}$ & $1.0 \mathrm{~m}$ \\
Depth 2 & $1.5 \mathrm{~m}$ & $1.5 \mathrm{~m}$ & $1.5 \mathrm{~m}$ \\
\hline
\end{tabular}


Table 2. Soil temperature range at $1.0 \mathrm{~m}$ and $1.5 \mathrm{~m}$ depth underground covered by three various soil surface conditions: bare, shaded and insulated.

\begin{tabular}{|c|c|c|c|c|}
\hline \multirow{2}{*}{ Depths } & \multirow{2}{*}{ Types of condition } & \multicolumn{2}{|c|}{ Temperatures, ${ }^{\circ} \mathrm{C}$} & \multirow{2}{*}{$\begin{array}{c}\text { Temperature Difference, } \\
\Delta \text { (Max-Min) }\end{array}$} \\
\hline & & Maximum & Minimum & \\
\hline \multirow{3}{*}{1.0 meter } & Bare Soil & 29.545 & 29.136 & $0.409^{\circ} \mathrm{C}$ \\
\hline & Shaded Soil & 27.669 & 27.318 & $0.351^{\circ} \mathrm{C}$ \\
\hline & Insulated Soil & 27.115 & 26.781 & $0.334^{\circ} \mathrm{C}$ \\
\hline \multirow{3}{*}{1.5 meters } & Bare Soil & 29.704 & 29.290 & $0.414^{\circ} \mathrm{C}$ \\
\hline & Shaded Soil & 27.904 & 27.546 & $0.358^{\circ} \mathrm{C}$ \\
\hline & Insulated Soil & 27.470 & 27.145 & $0.325^{\circ} \mathrm{C}$ \\
\hline
\end{tabular}

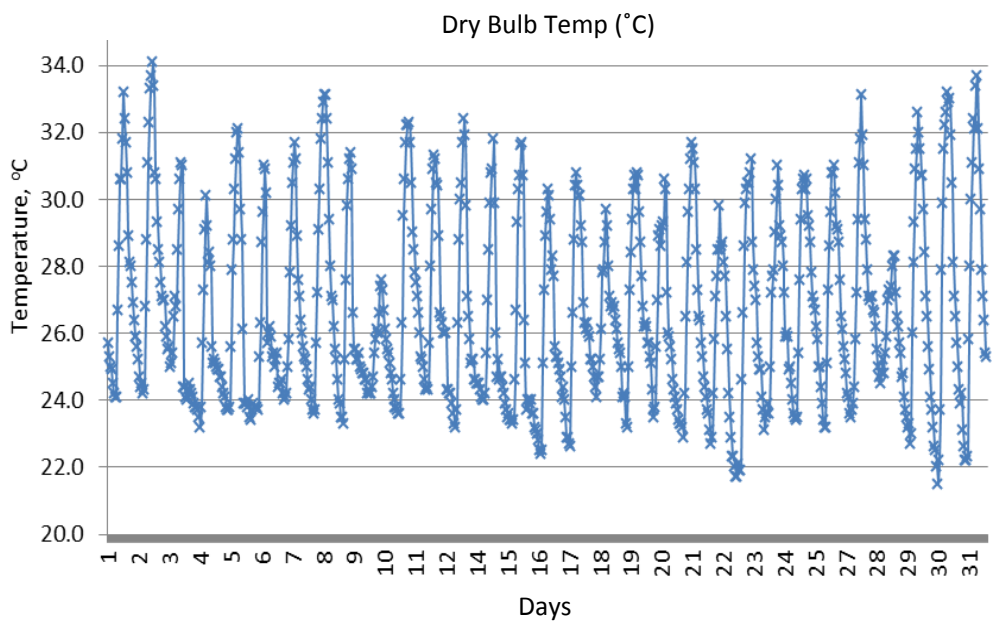

Figure 2. Dry Bulb Temperature for January 2014 (Source: Meteorology Department Malaysia, Subang weather station).

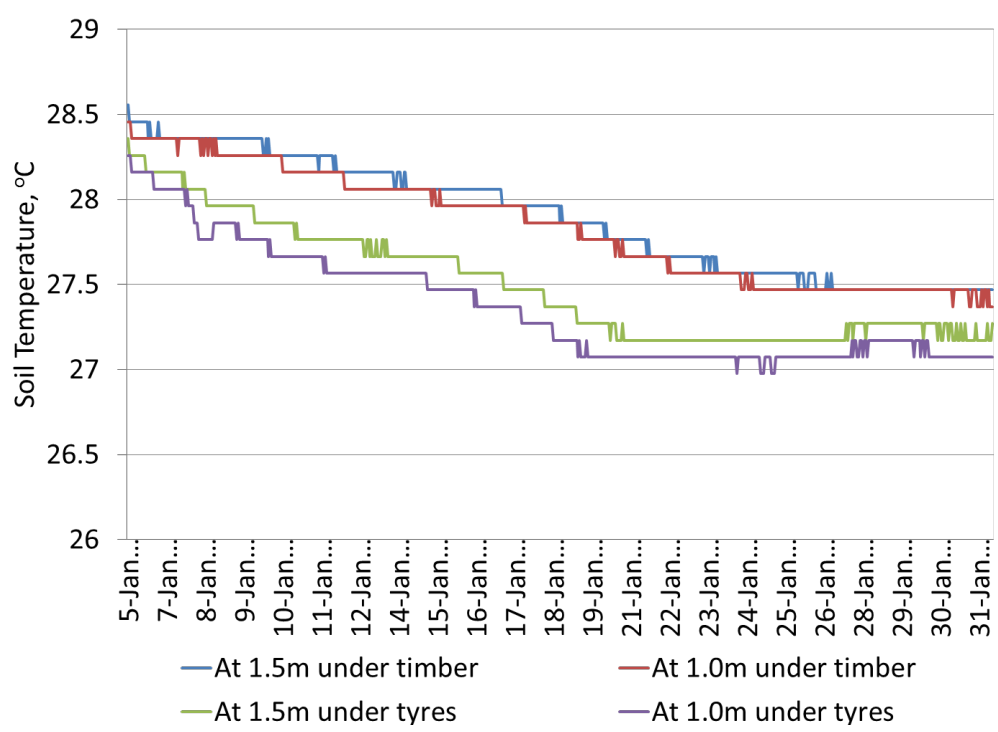

Figure 3. Soil temperature at $1.0 \mathrm{~m}$ and $1.5 \mathrm{~m}$ depth underground under three soil surface conditions, shaded by recycled timber pallette and insulated by used tyres. 
11:00 a.m. to 2:00 p.m. In average, the solar radiation ranges from $0 \mathrm{~W} / \mathrm{m}^{2}$ to $650 \mathrm{~W} / \mathrm{m}^{2}$ [7]. With high solar radiation intensity, the soil surface temperature gets heated up and heat transmits through the soil underground from the ground surface. This study intended to reduce the effect of solar radiation in transmitting heat through the soil underground and for that, this study has used two types of soil surface cover, as mentioned earlier, shaded by timber pallette and insulated by used tyres that are made of rubber. With heat storage capacity, these two materials are able to reduce the solar heat gain into the soil by shading or insulating the soil surface from direct solar radiation. This has been proven by the temperature differences between the soil temperature under bare soil and under shaded and insulated soil surface (Table 2).

Following the field investigation, the field data was inserted onto Energy Plus software to simulate the performance of EAHE Cooling in hot and humid Malaysia under three different soil surface: bare, shaded with timber pallette and insulated with used tyres. From simulation results below (Figure 5), it has shown a simulation of an improved performance of EAHE Cooling Technology in hot and humid climate Malaysia when the soil surface is sheltered from the sun solar radiation by covering the surface with timber pallette and used tyres. The graph in Figure 4 also shows that among the three surface conditions, the best result is performed by the soil surface sheltered by used tyres.

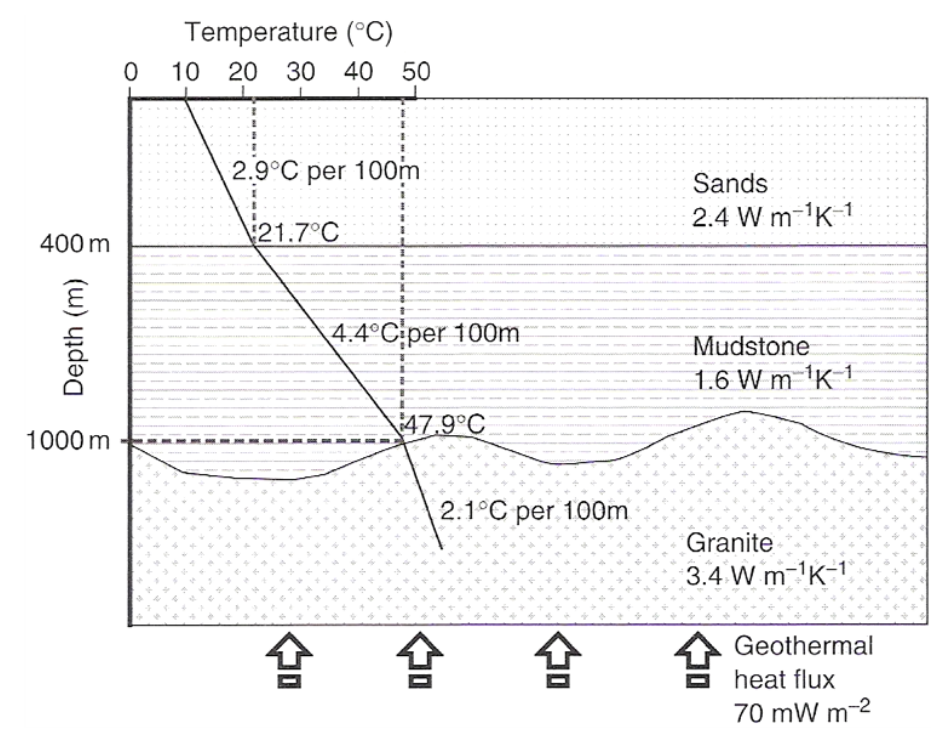

Figure 4. An example of geothermal gradient through a sample of earth structure (Source: Banks, 2008) [11].

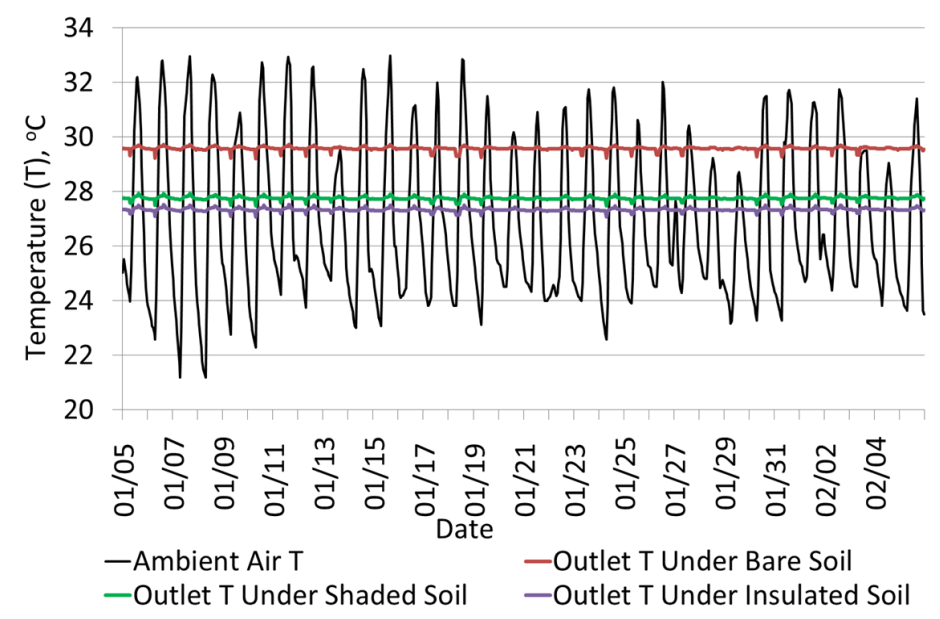

Figure 5. Ambient Temperature and EAHE Cooling outlet temperature for one month. 


\section{Conclusions}

From the results above, the objectives of this study are answered. Firstly, the study managed to obtain further temperature reductions of the soil underground for better heat transfer process of the EAHE Cooling buried pipes. Secondly, it has been proven that the soil surface condition with layers of used tyres provide the best cooled soil for EAHE Cooling Technology application. Finally, a simulation in Energy Plus has shown the positive effect of the cooled soil towards the EAHE cooling performance.

With a lower soil temperature, better heat exchange will occur in the EAHE Cooling Technology and a more cooling outlet temperature can be achieved for building cooling in Malaysia tropical climate.

\section{References}

[1] Krishnan, G. (2007) Putrajaya Is $5^{\circ} \mathrm{C}$ Hotter than Other Local Cities. The Star Archives. http://www.thestar.com.my/story.aspx/?file=\%2f2007\%2f6\%2f19\%2fcentral\%2f17992083\&sec=central

[2] Chan, S.A. (2004) Energy Efficiency-Designing Low Energy Buildings Using Energy 10. CPD Seminar, Pertubuhan Arkitek Malaysia, Kuala Lumpur.

[3] Mihalakakou, G., Santamouris, M., Asimakopoulos, D. and Tselepidaki, I. (1995) Parametric Prediction of the Buried Pipes Cooling Potential for Passive Cooling Applications. Solar Energy, 55, 163-173. http://dx.doi.org/10.1016/0038-092X(95)00045-S

[4] Ghosal, M.K. and Tiwari, G.N. (2006) Modelling and Parametric Studies for Thermal Performance of an Earth to Air Heat Exchanger Integrated with Greenhouse. Energy Conversion and Management, 47, 1779-1798. http://dx.doi.org/10.1016/j.enconman.2005.10.001

[5] Krarti, M. and Kreider, J.F. (1996) Analytical Model for Heat Transfer in an Underground Air Tunnel. Energy Conversion and Management, 37, 1561-1574. http://dx.doi.org/10.1016/0196-8904(95)00208-1

[6] Reimann, G., Boswell, H. and Bacon, S. (2007) Ground Cooling of Ventilation Air for Energy Efficient House in Malaysia: A Case Study of The Cooltek House. Conference on Sustainable Building South-East Asia (SB07SEA 5th to 7th), Kuala Lumpur, 5-7 November 2007.

[7] Sanusi, A.N.Z., Shao, L. and Ibrahim, N. (2013) Passive Ground Cooling System for Low Energy Buildings in Malaysia (Hot and Humid Climates). Renewable Energy, 49, 193-196. http://dx.doi.org/10.1016/j.renene.2012.01.033

[8] Givoni, B. (2007) Cooled Soil as a Cooling Source for Buildings. Solar Energy, 81, 316-328. http://dx.doi.org/10.1016/j.solener.2006.07.004

[9] Sanusi, A.N.Z. (2012) Low Energy Ground Cooling System for Buildings in Hot and Humid Malaysia. Ph.D. Thesis, International Islamic University Malaysia and De Montfort University, UK.

[10] http://www.onsetcomp.com/products/data-loggers/ua-001-08

[11] Banks, D. (2008) An Introduction to Thermogeology: Ground Source Heating and Cooling. Blackwell, UK. 
Scientific Research Publishing (SCIRP) is one of the largest Open Access journal publishers. It is currently publishing more than 200 open access, online, peer-reviewed journals covering a wide range of academic disciplines. SCIRP serves the worldwide academic communities and contributes to the progress and application of science with its publication.

Other selected journals from SCIRP are listed as below. Submit your manuscript to us via either submit@scirp.org or Online Submission Portal.
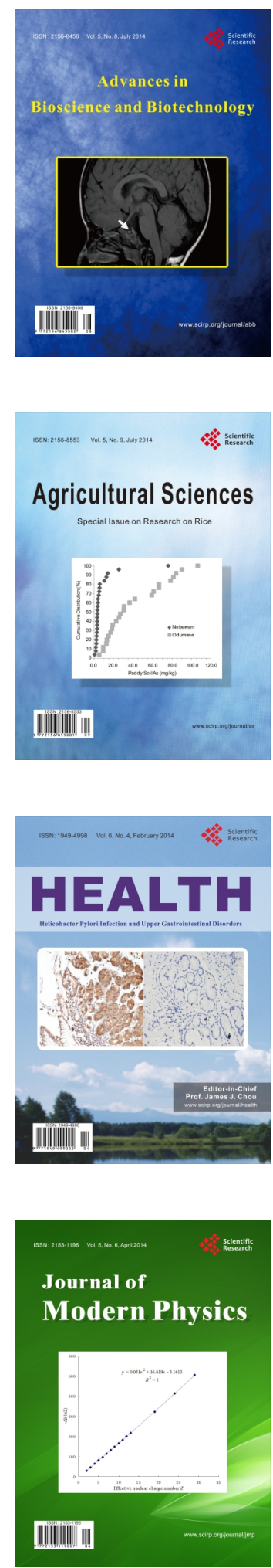
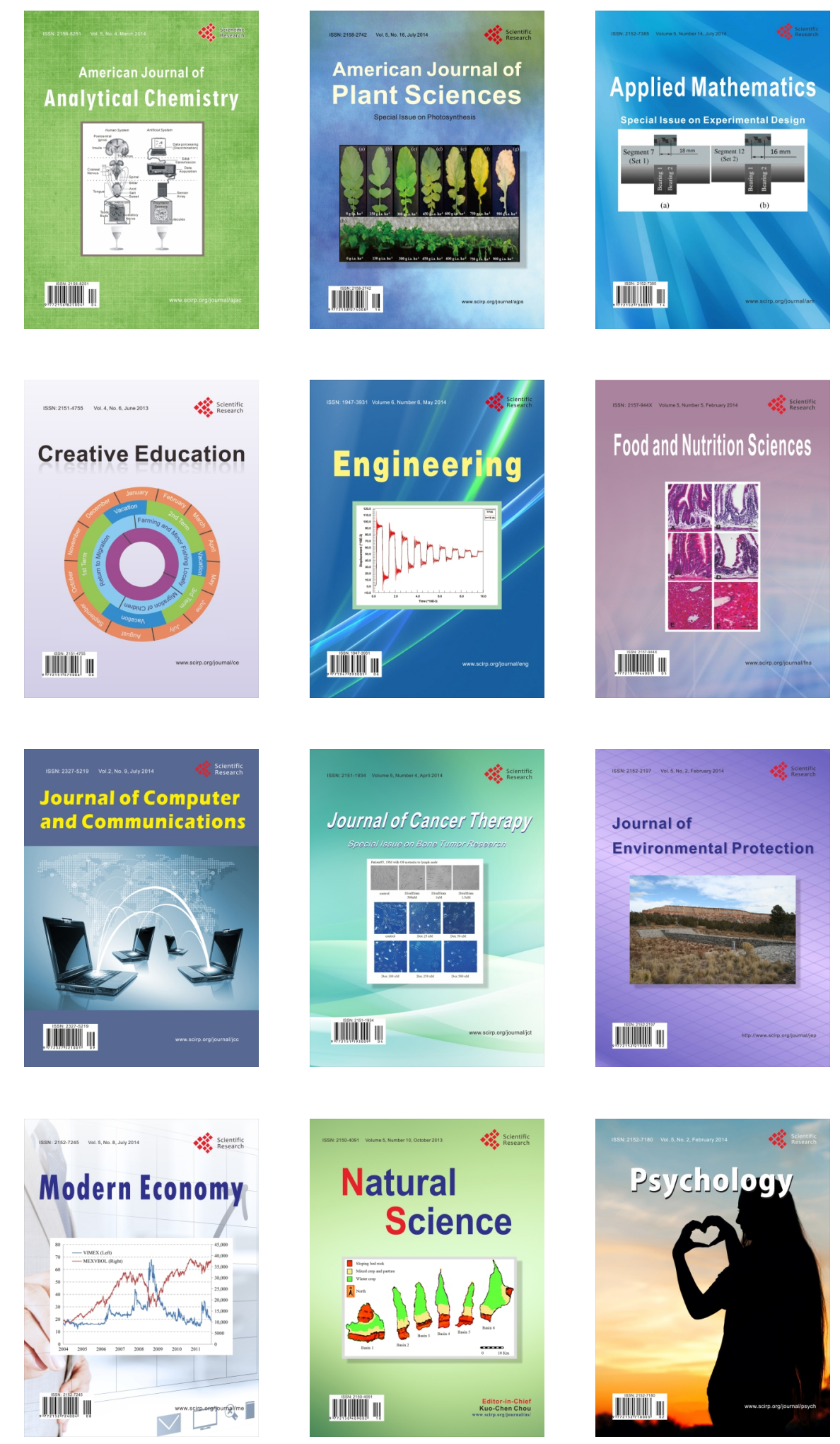